\title{
Effect of Environment-Friendly Non-Ionic Surfactant on Interfacial Tension Reduction and Wettability Alteration; Implications for Enhanced Oil Recovery
}

\author{
Omid Mosalman Haghighi ${ }^{1}$, Ghasem Zargar ${ }^{1}$, Abbas Khaksar Manshad ${ }^{1, *}$,

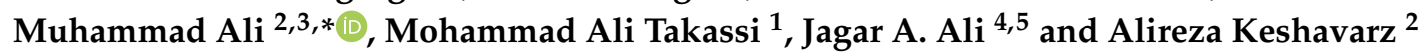 \\ 1 Department of Petroleum Engineering, Abadan Faculty of Petroleum Engineering, Petroleum University of \\ Technology (PUT), Abadan, Iran; haqiqiomid@yahoo.com (O.M.H.); zargar@put.ac.ir (G.Z.); \\ takassi@put.ac.ir (M.A.T.) \\ 2 School of Engineering, Edith Cowan University, Joondalup 6027, Australia; a.keshavarz@ecu.edu.au \\ 3 Western Australia School of Mines, Minerals, Energy and Chemical Engineering, Curtin University, \\ 26 Dick Perry Avenue, Kensington 6151, Australia \\ 4 Department of Petroleum Engineering, Faculty of Engineering, Soran University, Soran 44008, Kurdistan \\ Region, Iraq; jagar.pet@gmail.com \\ 5 Department of Petroleum Engineering, College of Engineering, Knowledge University, Erbil 44001, \\ Kurdistan Region, Iraq \\ * Correspondence: Khaksar@put.ac.ir (A.K.M.); muhammad.ali7@postgrad.curtin.edu.au (M.A.)
}

Received: 5 June 2020; Accepted: 28 July 2020; Published: 2 August 2020

\begin{abstract}
Production from mature oil reservoirs can be optimized by using the surfactant flooding technique. This can be achieved by reducing oil and water interfacial tension (IFT) and modifying wettability to hydrophilic conditions. In this study, a novel green non-ionic surfactant (dodecanoyl-glucosamine surfactant) was synthesized and used to modify the wettability of carbonate reservoirs to hydrophilic conditions as well as to decrease the IFT of hydrophobic oil-water systems. The synthesized non-ionic surfactant was characterized by Fourier transform infrared spectroscopy (FTIR) and chemical shift nuclear magnetic resonance (HNMR) analyses. Further $\mathrm{pH}$, turbidity, density, and conductivity were investigated to measure the critical micelle concentration (CMC) of surfactant solutions. The result shows that this surfactant alters wettability from $148.93^{\circ}$ to $65.54^{\circ}$ and IFT from 30 to 14 dynes $/ \mathrm{cm}$. Core-flooding results have shown that oil recovery was increased from $40 \%$ (by water flooding) to $59 \%$ (by surfactant flooding). In addition, it is identified that this novel non-ionic surfactant can be used in $\mathrm{CO}_{2}$ storage applications due to its ability to alter the hydrophobicity into hydrophilicity of the reservoir rocks.
\end{abstract}

Keywords: non-ionic surfactant; chemical enhanced oil recovery (EOR); wettability; Core-flooding; interfacial tension

\section{Introduction}

The world oil reserve is declining due to the high demand for fossil fuel and the lack of exploring giant new hydrocarbon reservoirs. So, optimizing the reserve in place can be a solution tackle this issue [1]. According to the proven oil reserves in the world, carbonate rocks make up about $50 \%$ of the world's oil reserves [2]. Currently, the oil industry is more focused to increase production from existing reservoirs by using enhanced oil recovery (EOR) methods [3,4]. EOR is commonly done after primary recovery (natural drainage) and secondary recovery (water-flood), which only enables 1/3rd recovery from oil reservoirs $[5,6]$. Hence, tertiary recovery methods, like chemical flooding, miscible and immiscible $\mathrm{CO}_{2}$ flooding, nanoparticle applications in EOR and in-situ thermal recovery methods 
play an important role in extracting residual crude oil from existing carbonate reservoirs [3,7-11]. Among all these tertiary recovery methods, chemical EOR flooding is attracting more attention due to its ability to reduce IFT, alter wettability to more water-wet conditions, and its low adsorption on rock matrix [12-17].

In Chemical EOR, Surfactants have been an integral part of the oil and gas industry and it continues to be of significance even today. Surfactants are also called surface-active agents, which are chemical substances that are adsorbed onto surfaces or interfaces of a system when present at low concentrations $[18,19]$. They can enhance oil recovery by modifying hydrophobic rock matrix to hydrophilic nature and by lowering interfacial tension (IFT), which can cause trapped crude oil in small pore spaces displaced and to be replaced by water [20-22]. This mechanism of the recovery process at pore scale is related with sweep efficiency, which is controlled by viscous and capillary forces and they can be determined from the relationship of IFT and contact angle (wettability measurements) [23-25].

Ali et al. $2019[23,26]$ have determined how reduced IFT and hydrophilic wettability positively affects capillary forces. Kamal et al. 2017 [5] have shown how oil saturation has decreased from $90 \%$ to $0 \%$ by increasing the capillary number from $10^{-7}$ and $10^{-6}$ to $10^{-3}$ and $10^{-2}$. To achieve these varieties, water and oil IFT must be decreased to $20-30 \mathrm{mN} / \mathrm{m}$, this can be possible by using the surfactant injection technique. Cayias et al. 1977 [27] have found that complex an-ionic surfactant mixtures can reduce IFT for water systems in combination with pristine hydrocarbons (HC). Al-Sabagh 2000 [28] synthesized eight low molecular weight non-ionic co-polyester (PE) surfactants for application in Enhanced Oil Recovery. By investigating their surface activity, it was found that the reduction in surface tension was decreased with an increasing number of ethylene oxide. Shuler et al. 2011 [29] investigated the performance of surfactants (nonionic and anionic) in cores with permeability from 2 to $10 \mathrm{mD}$. He found that adding surfactants to fracturing liquids has increased oil recovery by wettability alteration. Cheng and Kwan, 2012 [30], performed a surfactant pilot on fractured carbonate from the Yates field in West Texas and found that surfactant injection has reduced interfacial tension and increased oil recovery after primary depletion and water and gas injections. More recently, Jha et al. 2019 [21] have determined that how low salinity an-ionic surfactant (SDBS, $1.435 \mathrm{mM}$ ) augmented with $\left(\mathrm{ZrO}_{2}\right.$ nano-particles) was effective to reduce interfacial tension and hydrophobic wettability at reservoir conditions. He also showed how this surfactant can be used to improve oil recovery. Asl et al. (2020) [31] summarized previous work showing the effects of different surfactants on contact angle, oil recovery and interfacial tension (Table 1).

Several studies have used different surfactants, nano-particles and polymers to reduce the IFT and alerting wettability to more water-wet conditions for enhancing oil recovery and $\mathrm{CO}_{2}$-storage applications [32-37]. However, those surfactants, polymers and nano-particles can cause toxic effects in shallow water zones, while their injection into oil wells increases the production at onshore locations [38-41]. It can also be toxic to the marine environment when injected into oil wells for increasing production at offshore locations [42-46]. Sometimes, this activity may involve oil spills or injection fluid spills into marine environment that can cause a toxic effect on marine species. Therefore, it is of the utmost importance to introduce green surfactants which can perform well in increasing the recovery factor, as well as in the event of spills; it remains non-harmful to marine species at offshore locations. It can also be non-harmful while used in onshore locations, if it is introduced in shallow water zones.

The main goal of this study is to synthesize a new and novel green non-ionic surfactant (dodecanoyl-glucosamine surfactant), which is non-toxic to shallow water zones and marine environment, and performs well for reducing the IFT and altering wettability for increased oil production. The synthesized surfactant was characterized using nuclear magnetic resonance (NMR) and Fourier transform infrared spectroscopy (FT-IR). The effects of dodecanoyl-glucosamine surfactant at different concentrations were examined to investigate its effects on wettability alteration and interfacial tension (IFT) reduction for improving oil recovery in carbonate reservoirs. 
Table 1. Summary of previous work showing the effects of different surfactants on the interfacial tension (IFT), oil recovery and contact angle.

\begin{tabular}{|c|c|c|c|c|c|c|}
\hline \multirow{2}{*}{ Surfactant } & \multicolumn{2}{|c|}{ IFT, $\mathrm{mN} / \mathrm{m}$} & \multicolumn{2}{|c|}{ Contact Angle, Degree } & \multirow{2}{*}{$\begin{array}{c}\text { Recovery } \\
\text { Factor (RF) \% }\end{array}$} & \multirow[b]{2}{*}{ References } \\
\hline & $\begin{array}{c}\text { Without } \\
\text { Surfactant }\end{array}$ & $\begin{array}{c}\text { With } \\
\text { Surfactant }\end{array}$ & $\begin{array}{c}\text { Without } \\
\text { Surfactant }\end{array}$ & $\begin{array}{c}\text { With } \\
\text { Surfactant }\end{array}$ & & \\
\hline$(\mathrm{C} 12 \mathrm{mim})(\mathrm{Cl})$ & 27.55 & 6.33 & - & - & - & $\begin{array}{l}\text { Manshad et al. } \\
\text { (2017) [47] }\end{array}$ \\
\hline$(\mathrm{C} 18 \mathrm{mim})(\mathrm{Cl})$ & 27.55 & 1.20 & 149 & 124 & 48 & - \\
\hline$(\mathrm{C} 8 \mathrm{Py})(\mathrm{Cl})$ & 27.55 & 19.05 & - & - & - & - \\
\hline$(\mathrm{C} 18 \mathrm{Py})(\mathrm{Cl})$ & 27.55 & 1.81 & 142 & 120 & 43 & - \\
\hline CTAB & - & 0.050 & 140 & 56 & - & $\begin{array}{l}\text { Hou et al. } \\
\text { (2015) [48] }\end{array}$ \\
\hline TX-100 & - & 0.322 & 140 & 98 & - & - \\
\hline POE & - & 2.329 & 140 & 110 & - & - \\
\hline $\begin{array}{l}\text { lauroyl } \\
\text { arginine } \\
\text { (L-Arg) }\end{array}$ & 34.5 & 18 & 144 & 78 & 55.6 & $\begin{array}{l}\text { Asl. et al. } \\
\text { (2020) [31] }\end{array}$ \\
\hline $\begin{array}{l}\text { lauroyl } \\
\text { cysteine } \\
\text { (L-Cys) }\end{array}$ & 34.5 & 15.4 & 144 & 75 & 52.6 & - \\
\hline$(\mathrm{C} 12 \mathrm{mim})(\mathrm{Br})$ & 43.97 & 9.10 & - & - & & $\begin{array}{l}\text { Nabipour et al. } \\
\text { (2017) [49] }\end{array}$ \\
\hline$(\mathrm{C} 14 \mathrm{mim})(\mathrm{Br})$ & 43.97 & 7.20 & - & - & & - \\
\hline$(\mathrm{C} 16 \mathrm{mim})(\mathrm{Br})$ & 43.97 & 4.70 & - & - & 75.6 & - \\
\hline CTAB & 43.97 & 7.70 & - & - & 71 & - \\
\hline $\begin{array}{c}\text { Henna } \\
\text { extract } \\
\mathrm{TiO}_{2+}\end{array}$ & 37 & 15.24 & - & - & - & $\begin{array}{c}\text { Tavakoli et al. } \\
\text { (2020) [50] }\end{array}$ \\
\hline $\begin{array}{l}\text { Henna } \\
\text { extract }\end{array}$ & 37 & 14.57 & - & - & - & - \\
\hline $\begin{array}{c}\text { Mulberry } \\
\text { Leaf Extract }\end{array}$ & 42 & 20 & 150 & 30 & 63 & $\begin{array}{l}\text { Ravi et al. } \\
\text { (2015) [51] }\end{array}$ \\
\hline
\end{tabular}

\section{Experimental}

\subsection{Materials}

Chemical reagent (Glucosamine) was used to make surfactant formulation (from Sigma Aldrich, 99\% purity) by mixing with de-ionized water (Ultrapure, from David Gray, electrical conductivity $=0.02 \mathrm{mS} / \mathrm{cm}$ ) using a magnetic stirrer. Synthetic seawater (SSW) of $1.42 \mathrm{cP}$ viscosity and $1.068 \mathrm{~g} / \mathrm{cm}^{3}$ density was used in experiments by dissolving Sodium Chloride $(\mathrm{NaCl}$ from rowe scientific, purity $>99.9 \mathrm{~mol} \%$ ) with deionized water to make $100,000 \mathrm{ppm}$ of $\mathrm{NaCl}$ brine. Methanol, acetone, ethanol (from Chem supply, purity > $99.9 \mathrm{~mol} \%$ ), and toluene (from Chem-Supply; >99 mol\%) were used to clean rock surface from prevailing impurities. Ahwaz oilfield crude oil was used in this study with API gravity of 32.6, density $0.878 \mathrm{~g} / \mathrm{cm}^{3}$, and viscosity $13.23 \mathrm{cP}$. Nonetheless, for contact angle and interfacial tension measurements, kerosene (from Rowe Scientific; purity $\geq 99.9 \mathrm{~mol} \%$ ) with the viscosity of $(1.32 \mathrm{cP})$ and density of $\left(0.79 \mathrm{dm} / \mathrm{cm}^{3}\right)$ was used. The carbonate rock samples (dimensions $3.8 \mathrm{~mm}$ diameter and $68 \mathrm{~mm}$ length) in this study were acquired from Baba Koohi outcrop in Iran. The porosity of these samples ranged between $13.7 \%$ and $14.5 \%$ and liquid permeability of these samples ranged between 4.8 and $5.3 \mathrm{mD}$ with Pore Volume (PV) ranging from 7.9 and $8.1 \mathrm{cc}$.

\subsection{Synthesis of Dodecanoyl-Glucosamine Surfactant}

To prepare dodecanoyl-glucosamine surfactant, $1.0 \mathrm{~g}$ of glucosamine was dissolved in $10 \mathrm{~mL}$ of de-ionized water in a small beaker. A total of $90.0 \mathrm{~mL}$ of methanol was poured in a $250 \mathrm{~mL}$ round bottom flask with a magnetic stirring bar. The glucosamine solution was added slowly to methanol while it was stirred by a magnetic stirrer. A clear solution was obtained following 
$3.0 \mathrm{~mL}$ of lauryl chloride being added to the methanol solution. The solution was stirred for $24 \mathrm{~h}$ at room temperature. The dodecanoyl-glucosamine surfactant was obtained as a white precipitate. The precipitate was collected and then recrystallized in ethanol. The melting point (decomposition point) of the dodecanoyl-glucosamine surfactant is $158^{\circ} \mathrm{C}$. The synthesis is demonstrated in Scheme 1 and the materials used in the synthesis are described in Table 2.

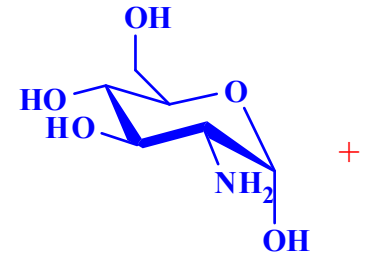

Glucosamine<smiles>CCCCCCCCCCCC(=O)Cl</smiles>

Lauryl chloride

Methanol

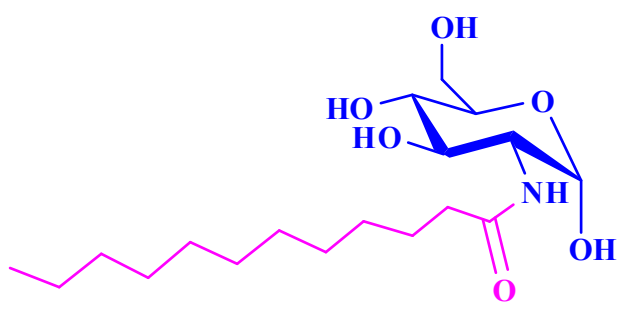

Lauryl glucosamide

Scheme 1. Synthesis of dodecanoyl-glucosamine surfactant.

Table 2. Specifications of used chemicals.

\begin{tabular}{ccccc}
\hline Organic Acid & $\begin{array}{c}\text { Molar Mass } \\
(\mathrm{g} / \mathbf{m o l})\end{array}$ & Formula & $\begin{array}{c}\text { Density } \\
\left(\mathrm{g} / \mathrm{cm}^{3}\right)\end{array}$ \\
Glucosamine & 179.17 & $\mathrm{C}_{6} \mathrm{H}_{13} \mathrm{NO}_{5}$ & 1.563 & \\
$\begin{array}{c}\text { Lauryl } \\
\text { Chloride }\end{array}$ & 218.765 & $\mathrm{C}_{12} \mathrm{H}_{23} \mathrm{ClO}$ & 0.946 & \\
Methanol & 32.04 & $\mathrm{CH}_{3} \mathrm{OH}$ & 0.792 & \\
\hline
\end{tabular}

\subsection{Mechanistic Quantification of Critical Micelle Concentration (CMC)}

There are many ways in which CMC could be determined. In this study, four methods for measuring the $\mathrm{CMC}$ were used, including $\mathrm{pH}$ (by Mettler Toledo pH-meter), electrical conductivity (by JEN-WAY-4510 conductivity meter), turbidity (by AL250T-IR turbidity meter) and density (by DA-640 KEN density meter at ambient conditions). To do this, various solutions of surfactant samples in deionized-water were prepared in the range 100-10,000 ppm. At first, 10,000 ppm solution of surfactant was made, then diluted surfactant solutions were prepared by gradual dilution of 10,000 ppm solution with deionized water. 


\subsection{Core Cleaning and Core Ageing Procedure}

It is important to clean the core samples to a water-wet state that precedes the accumulation of oil. In this study, the Soxhlet extraction method was used to clean the core samples with toluene and methanol as solvents. The soxhlet extraction system is used to dissolve hydrocarbon and formation brine from plug samples with the help of toluene and methanol, respectively.

It is believed that carbonate rock generally has oil-wetting behavior which attributes to the oil aging effect. After the cleaning process, to simulate the real formation, the thin sections of core samples were placed in a beaker together with crude oil from the Ahwaz oil field in the oven at $80^{\circ} \mathrm{C}$ under vacuum conditions for $48 \mathrm{~h}[10,11]$, to achieve initial oil saturation. After saturating the core samples with crude oil, the thin section was saturated with formation surfactant (dodecanoyl-glucosamine surfactant) for $24 \mathrm{~h}$ to reduce the wettability to more water-wet conditions. Figure 1 shows crude oil and thin sections of rock samples.

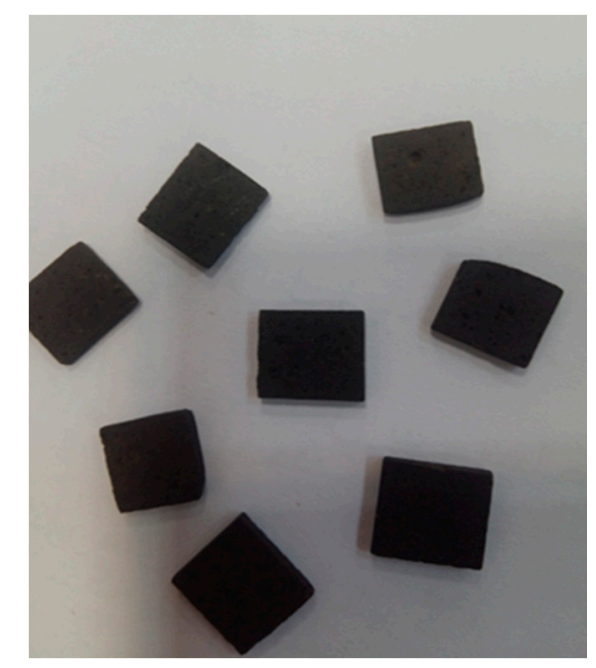

Figure 1. Carbonate rock thin sections from Baba Koohi outcrop formation from Shiraz, Iran.

\subsection{IFT Measurement Systems}

The interfacial tension (IFT) experiments were conducted with the contact angle method to find the tension between two liquid phases at ambient pressure and temperature conditions (by VIT-600 apparatus manufactured by Fars, accuracy $99 \%$ as shown in Figure 2a). In this method, a drop of surfactant liquid is dispensed from a needle in the presence of kerosene and all this process is video recorded. This process was repeated with different concentrations of surfactant solutions $(100-8000 \mathrm{ppm})$ and kerosene. The images are taken from a video where the drop is about to leave the needle while making a spherical shape at the tip of the needle. The shape of the drop is due to the relationship between surface tension and gravity. It can be represented by Equation (1) and Figure $2 \mathrm{~b}$

$$
\gamma=\frac{\Delta \rho g D^{2}}{H}
$$

where " $g$ " is the acceleration of gravity, " $\Delta \rho$ " is the density difference of two fluids, " $H$ " is the drop shape coefficient and " $D$ " is the diameter measured at maximum length for the droplet. 

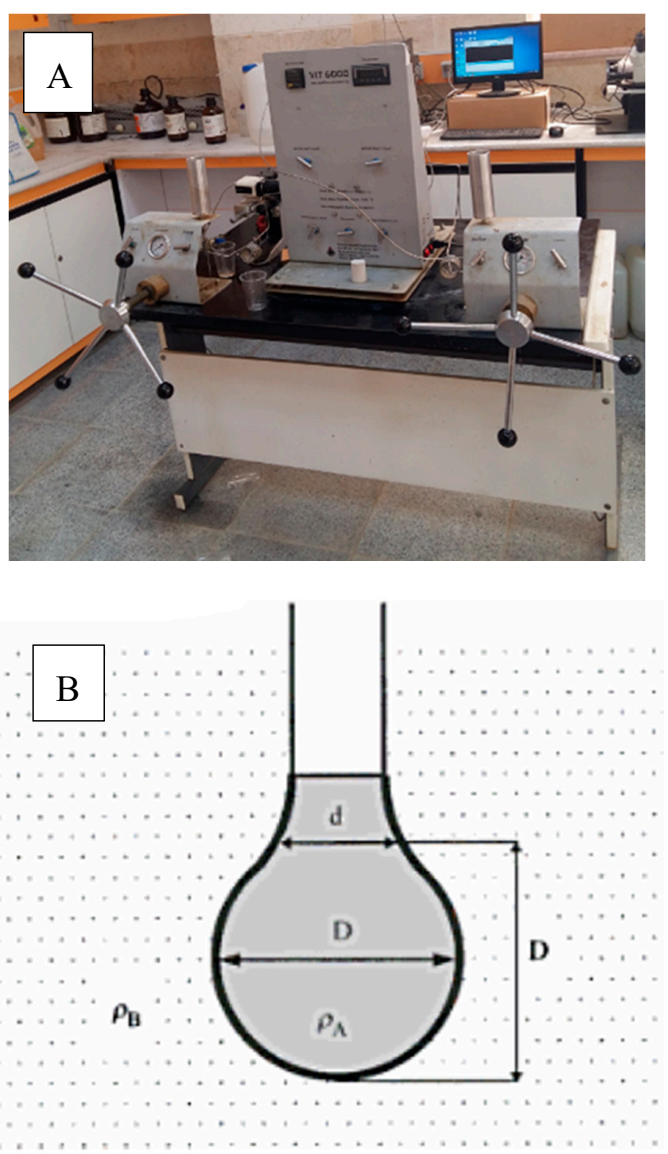

Figure 2. (A) Contact angle Interfacial Tension Experimental Setup (VIT-6000) (B) Typical digitized droplet in IFT measurement by VIT-600 pendant drop apparatus.

\subsection{Contact Angle Measurement System}

Contact angle measurement is the most effective method which is widely used to quantify the wetting characteristics of reservoir rock in the presence of two fluids $[21,24,25,52-54]$. This method can be performed in real reservoir conditions or ambient conditions. In this study, the VIT 6000 is used to investigate the wettability alteration of thin sections of carbonate formation. For this, thin sections are suspended horizontally in kerosene and the surfactant drop is dispensed from the top needle. This process is also video-recorded and images are taken when the drop touches to the thin section surface. Further, drop shape is analyzed and tangent angles are measured to quantify the wetting state of the rock (as shown in Figure 3).

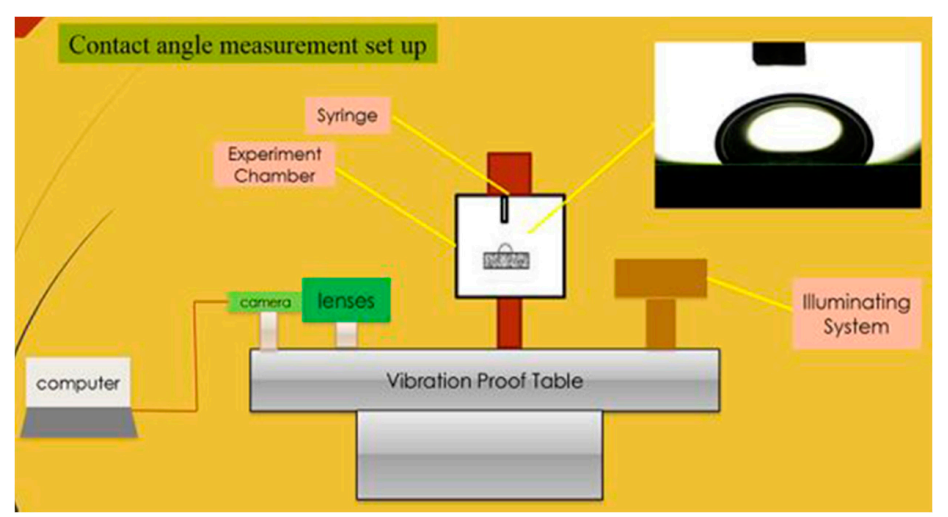

Figure 3. Schematic Image of Contact Angle Measurement Apparatus. 


\subsection{Core Flooding Measurements}

In this study, the core flooding test was performed to find the recovery factor after brine flooding and surfactant flooding. For measuring initial water saturation (Swi), original oil in place (OOIP), and residual oil saturation (Sor), core samples were initially saturated with distilled water. For this, core samples were loaded in the core holder followed by vacuuming the core samples for $24 \mathrm{~h}$ until there were no air bubbles remaining in the rock pore matrix. After that, they were flooded with 5 pore volume (PV) of distilled water at a constant pressure of 2000 psi (pressure was controlled by ISCO pumps from inlet end and with back pressure regulator from outlet end) until there was stable pressure drop at inlet and outlet ends. Overburden pressure was set at 2500 psi, 500 psi more than injection pressure to keep samples in place. After achieving stable pressure at inlet and outlet ends by injecting $5 \mathrm{PV}$ of distilled water, injection flow was stopped and pressure was maintained at $2000 \mathrm{psi}$ for $24 \mathrm{~h}$ to allow $100 \%$ saturation throughout the rock matrix. After the saturation process, absolute permeability was measured by injecting distilled water at three different flow rates of $0.1,0.3$, and $0.5 \mathrm{~mL} / \mathrm{min}[1,2]$. Further, crude oil from Ahwaz oilfield was injected to measure initial water saturation (Swi). For this, crude oil was injected at $2000 \mathrm{psi}$ with a constant flow rate of $0.2 \mathrm{~mL} / \mathrm{min}$ until there was no more water produced. The reason behind the low flow rate is the complex lithology of carbonate formation used in this study. As it has already been mentioned earlier that the permeability of these rock samples ranged between 4.8 and $5.3 \mathrm{mD}$, a higher flow rate will not guarantee proper passing of crude oil from the rock matrix due to its low permeability; instead, it will bypass the complex rock matrix towards the outlet end. The pressure range for the reservoir formation investigated in this study was between 1800 and $2200 \mathrm{psi}$. To mimic the real reservoir conditions, we have maintained $2000 \mathrm{psi}$ of inlet pressure. Further back pressure regulator (operated by nitrogen gas) was used to maintain the reservoir pressure of $2000 \mathrm{psi}$ at the outlet end. During crude oil injection, the production of distilled water was monitored to find a breakthrough point for two-phase production (water and crude oil), as well as one phase production (crude oil only) to quantify the Swi and OOIP. For brine injection, 50,000 ppm concentration of $\mathrm{NaCl}$ brine with deionized water was prepared and introduced in rock matrix after crude oil injection. Brine was also injected at 2000 psi with a constant flow rate of $0.2 \mathrm{~mL} / \mathrm{min}$ until there was no more production of crude oil. Similarly, crude oil production was monitored to find a breakthrough point for two-phase production (crude oil and brine), as well as one phase production (brine only) to quantify residual oil saturation (Sor) and recovery factor (RF). In addition to this, synthesized dodecanoyl-glucosamine surfactant (concentration of $843 \mathrm{ppm}$ based on CMC values) was injected at 2000 psi with a constant flow rate of $0.2 \mathrm{~mL} / \mathrm{min}$. Similarly, brine and trapped crude oil production were monitored to find a breakthrough point for three-phase production (crude oil, brine, and surfactant), as well as one phase production (surfactant only) to quantify the recovery factor. Figure 4 depicts the core flooding scheme.

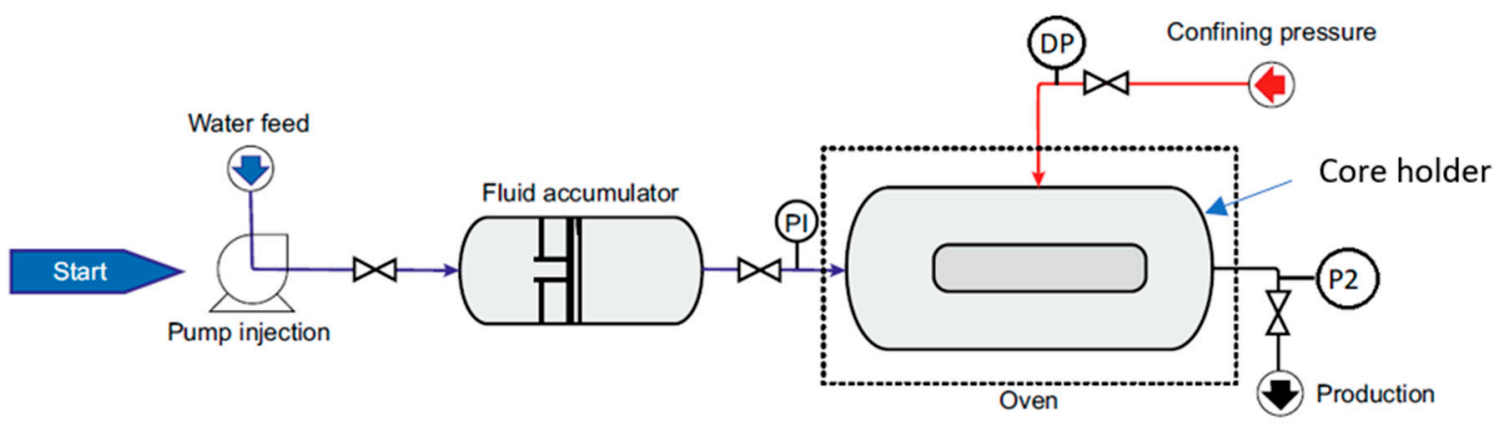

Figure 4. Schematic of core flooding experiments modified after [31]. 


\section{Results and Discussion}

\subsection{Characterization of Dodecanoyl-Glucosamine Surfactant}

Produced material was purified via ethanol crystallization, thereafter, crystallized powder was extracted at maximum for the melting point by drying it for $24 \mathrm{~h}$ at $80^{\circ} \mathrm{C}$. For further quantification, the synthesized powder was characterized by H-NMR and FT-IR [55-57]. In the ${ }^{1} \mathrm{H}-\mathrm{NMR}$ spectrum (as shown in Figure 5), the appeared peak depicted as 2H represents methylene group of the hydrocarbon tail. The appeared peaks at 3.7 ppm was due to the $\mathrm{CH}$ chiral centers near hydroxyl groups and $\mathrm{CH}_{2}-\mathrm{OH}$. The presence of a methyl group with amide group showed a triplet peak at 2.6 ppm. Merger of some methylene protons were also noted. The magnetic resonance showed the values at around $2.6 \mathrm{ppm}$ for these protons, represented as $1 \mathrm{H}$. The methyl group of the hydrocarbon tail has also appeared at $1 \mathrm{ppm}$. Additionally, the triplet spectrum at $1 \mathrm{ppm}$ depicts the methyl group with an integral of $3 \mathrm{H}$. This triplet pattern has two neighboring hydrogen on nearby carbons.

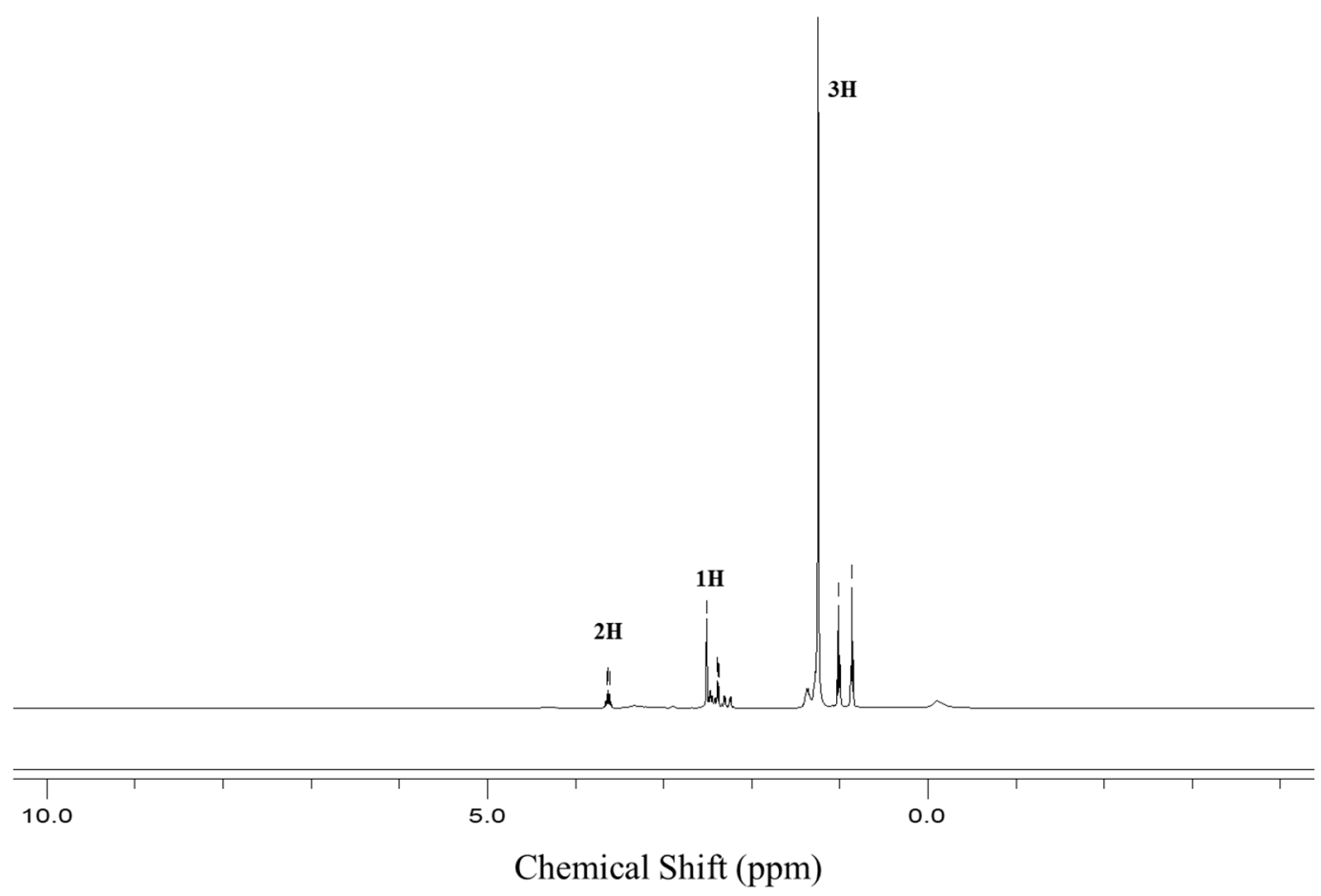

Figure 5. H-NMR of Dodecanoyl-Glucosamine Surfactant.

For the FT-IR spectrum (as shown in Figure 6), the absorption at $3347 \mathrm{~cm}^{-1}$ is allocated to the N-H stretching. The captivation band at $2941 \mathrm{~cm}^{-1}$ shows aliphatic hydrogen-bonding characteristics. The peak which appeared at $1617 \mathrm{~cm}^{-1}$ is a carbonyl peak in the amide group. The peaks which appeared at 1584 and $1538 \mathrm{~cm}^{-1}$ are depicted as $\mathrm{N}-\mathrm{H}$ symmetric and asymmetric in-plane bending of amide groups. The peak which is shown at $1094 \mathrm{~cm}^{-1}$ is the stretching band of $\mathrm{C}-\mathrm{O}$ and the peak depicted at $732 \mathrm{~cm}^{-1}$ is due to the $\mathrm{N}-\mathrm{H}$ out-of-plane bending.

\subsection{Critical Micelle Concentration Measurements}

The CMC identification process is dependent on surface tension measurements at each concentration for different concentrations of purified surfactant. This measurement will continue until surface tension does not decrease further; this point is attributed to the point where micelles start to form. This is called CMC regression analysis. In this study, Critical Micelle Concentration of dodecanoyl-glucosamine surfactant was measured by $\mathrm{PH}$ meter, Electrical Conductivity, Density Measurement, and Evaluation of Turbidity. Figure 7 depicts the results for the density, 
electrical conductivity, $\mathrm{pH}$, and turbidity of the dodecanoyl-glucosamine surfactant at different concentrations from 100 to $10,000 \mathrm{ppm}$. It is shown from the figure that CMC from measured values of density, electrical conductivity, $\mathrm{pH}$, and turbidity was $919,850,800$, and $800 \mathrm{ppm}$, respectively. Based on measured values, the concentration of $843 \mathrm{ppm}$ has been selected as the optimum CMC for the dodecanoyl-glucosamine surfactant.

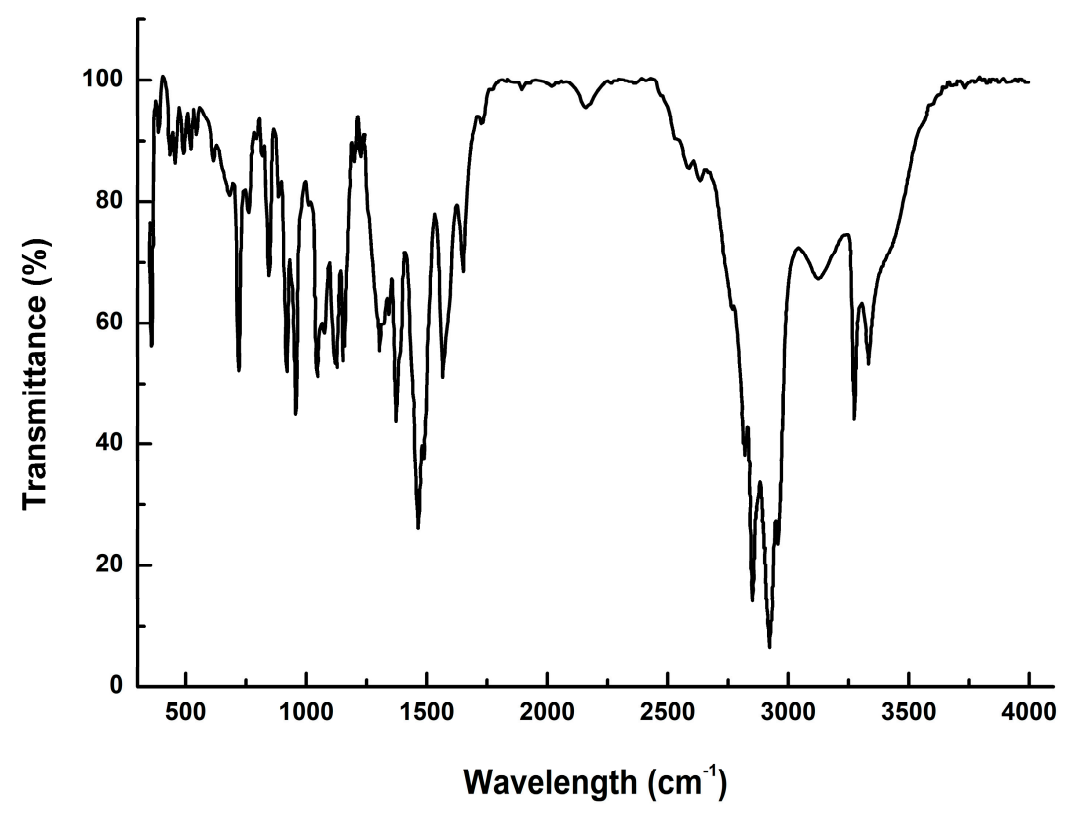

Figure 6. FT-IR of Dodecanoyl-Glucosamine Surfactant.
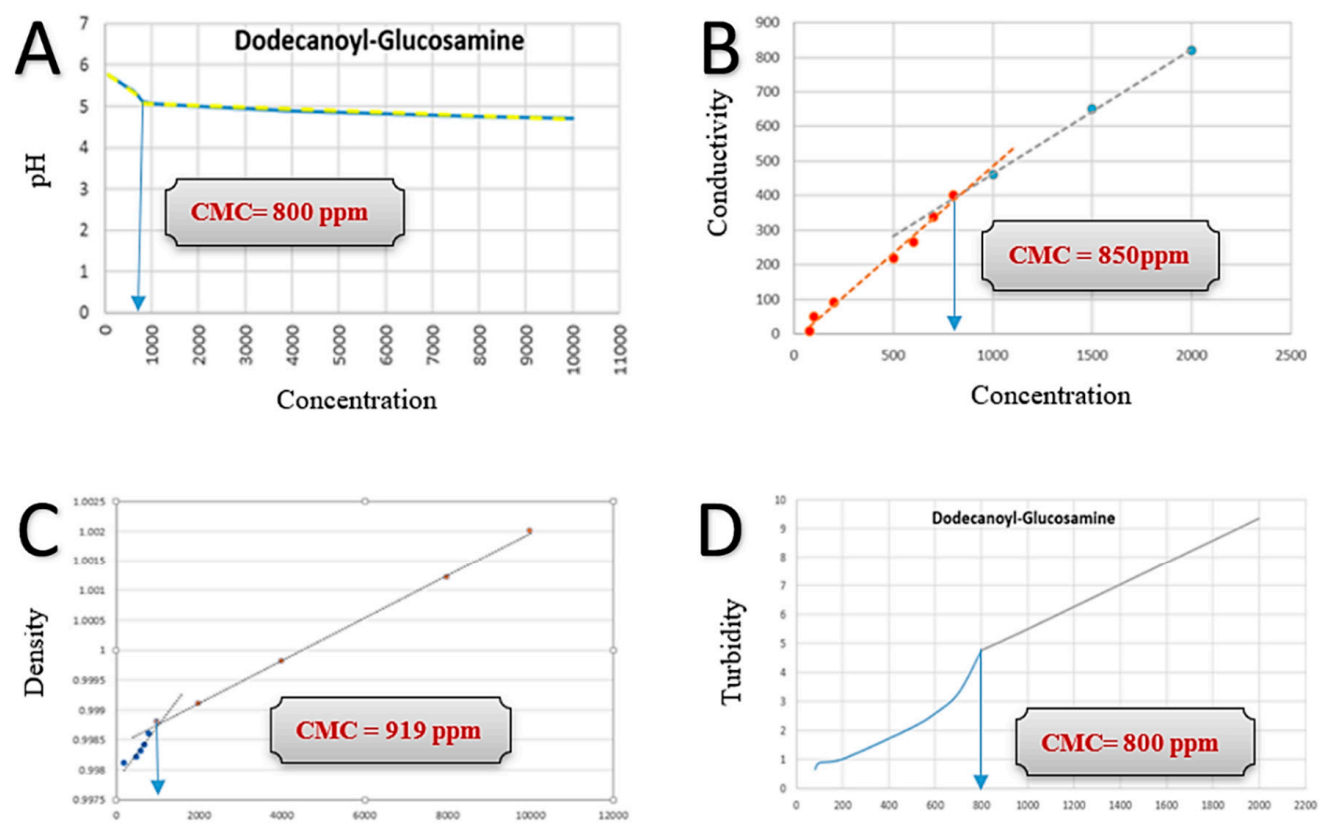

Figure 7. Determination of critical micelle concentration (CMC) of dodecanoyl-glucosamine surfactant via different methods. (A) Potential hydrogen of different solutions, a change in slope referred as the CMC. (B) Electrical conductivity of different concentrations of the solution, a change in the slope as CMC. (C) Density of different concentrations of the solution, a change in the slope as CMC. (D) Turbidity of different concentrations of the solution, linearity in increase in the solution determines the CMC. 


\subsection{Interfacial Tension Measurements}

In order to measure the IFT between two fluids, different concentrations of the dodecanoyl-glucosamine surfactant were prepared. The chosen concentrations for this measurement were 100, 200, 400, 500, 800, 1500, 6000, and 8000 ppm. It is shown from Figure 8 that with the increase in surfactant concentration, the values of IFT are decreasing in the presence of kerosene, as also depicted by a previous study [58], where the different concentrations of sodium ethyl ester sulfonate surfactant were synthesized for measurement of IFT reduction in the presence of kerosene. It is shown from the measured values of IFT between the dodecanoyl-glucosamine surfactant and kerosene that IFT values are higher in the higher concentrations, and it rapidly decreases as the concentration of surfactant decreases up to optimum surfactant concentration and, thereafter, the decrease in IFT values is very minimal, as shown in Figure 8. For example, the IFT value for 100 ppm surfactant concentration is $30.367 \mathrm{mN} / \mathrm{m}$, as compared to the $1500 \mathrm{ppm}$ surfactant concentration where IFT value rapidly decreased to $18.042 \mathrm{mN} / \mathrm{m}$. It is also shown from Figure 8 that $1500 \mathrm{ppm}$ is the optimum rapid reduction surfactant concentration value and, after that, the decrease in IFT is very minimal. For instance, at $8000 \mathrm{ppm}$ surfactant concentration, the value of IFT is $14.147 \mathrm{mN} / \mathrm{m}$ compared to the $18.0142 \mathrm{mN} / \mathrm{m}$ IFT value for $1500 \mathrm{ppm}$ of surfactant concentration. Further, the shapes of droplets in IFT measurements are shown in Figure 9.

\subsection{Contact Angle Measurements}

Wettability is a very crucial factor in determining the recovery factor for any reservoir. There are different methods used for measuring the wetting state of rock, but the most-used method is the contact angle method. This method is used to measure the contact angle between wetting and non-wetting phase [59-61]. In this study, contact angle values between dodecanoyl-glucosamine surfactant and kerosene were conducted as shown in (Figure 10). The results show that a higher concentration of surfactant produced higher contact angles and, as the concentration of surfactant was reduced, contact angle was also reduced gradually. This is due to the effect of a lower concentration of surfactant solution, which is optimal for lowering the wettability [16,21,22]. For instance, at 10,000 ppm of surfactant concentration, contact angle was measured at $65.54^{\circ}$, whereas at 100 ppm of surfactant concentration, contact angle was at the highest value of $148.93^{\circ}$.

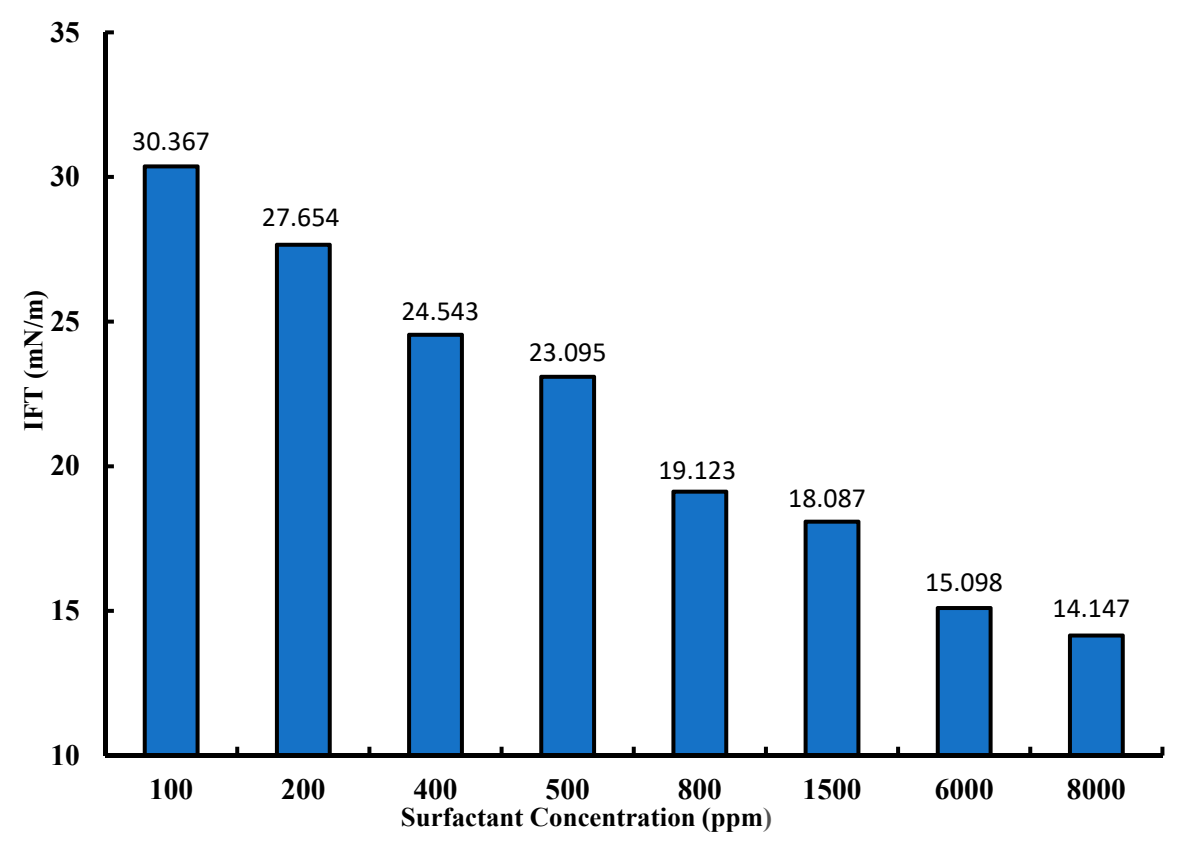

Figure 8. IFT V/S dodecanoyl-glucosamine surfactant concentrations. 

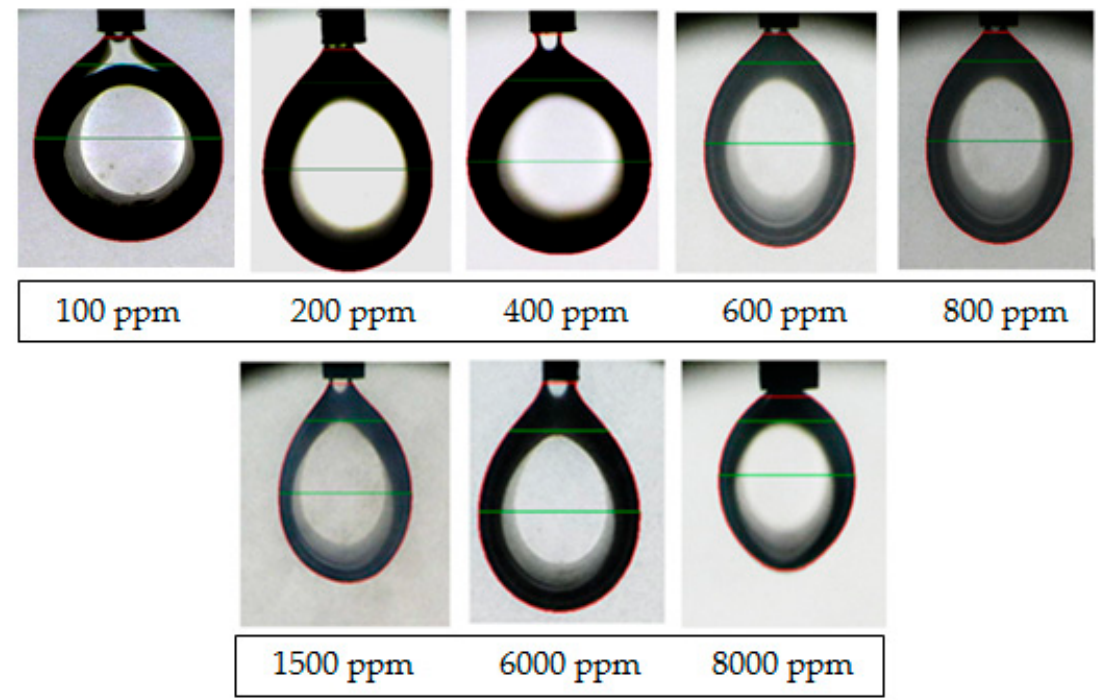

Figure 9. Droplet shapes of dodecanoyl-glucosamine surfactant V/S Kerosene.

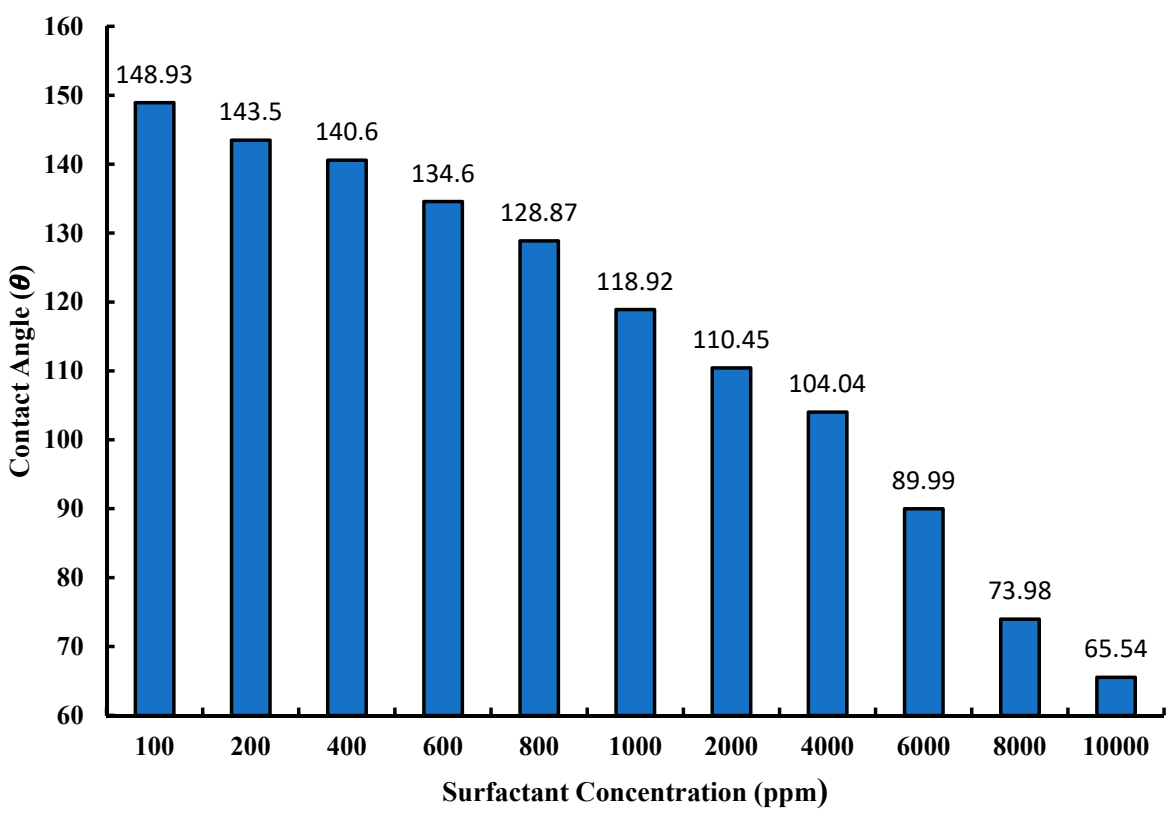

Figure 10. Contact Angle V/S dodecanoyl-glucosamine surfactant concentrations.

\subsection{Core Flooding}

In this study, core flooding test was conducted at three different scenarios, which included saturating the core sample with distilled water followed by crude oil flooding, Brine flooding and surfactant flooding. Initially, rock sample was saturated with distilled water (described in Section 2.7), followed by crude oil injection from Ahwaz oilfield to measure the Swi and OOIP. The total pore volume of the core sample was 8.05 cc. After crude oil injection (described in Section 2.7) Swi value was $2.95 \mathrm{cc}(35.11 \%)$ and the OOIP value was $5.1 \mathrm{cc}(63.35 \%)$. Thereafter, brine was injected (described in Section 2.7) to measure recovery factor of crude oil, that was $2.05 \mathrm{cc}(40.19 \%)$ and, based on calculation, Sor value was $3.05(59.8 \%)$. This is the volume of oil that remains un-producible after brine injection due to capillary trapping. Further, surfactant injection (as described in Section 2.7) was performed to acquire further oil recovery after brine injection. This method was successful in producing further crude oil of $0.96 \mathrm{cc}(18.81 \%)$, adding to crude oil recovery after brine injection. The recovery factor and pressure drop based on pore volumes during brine and surfactant injection is shown in Figure 11a,b, respectively. 

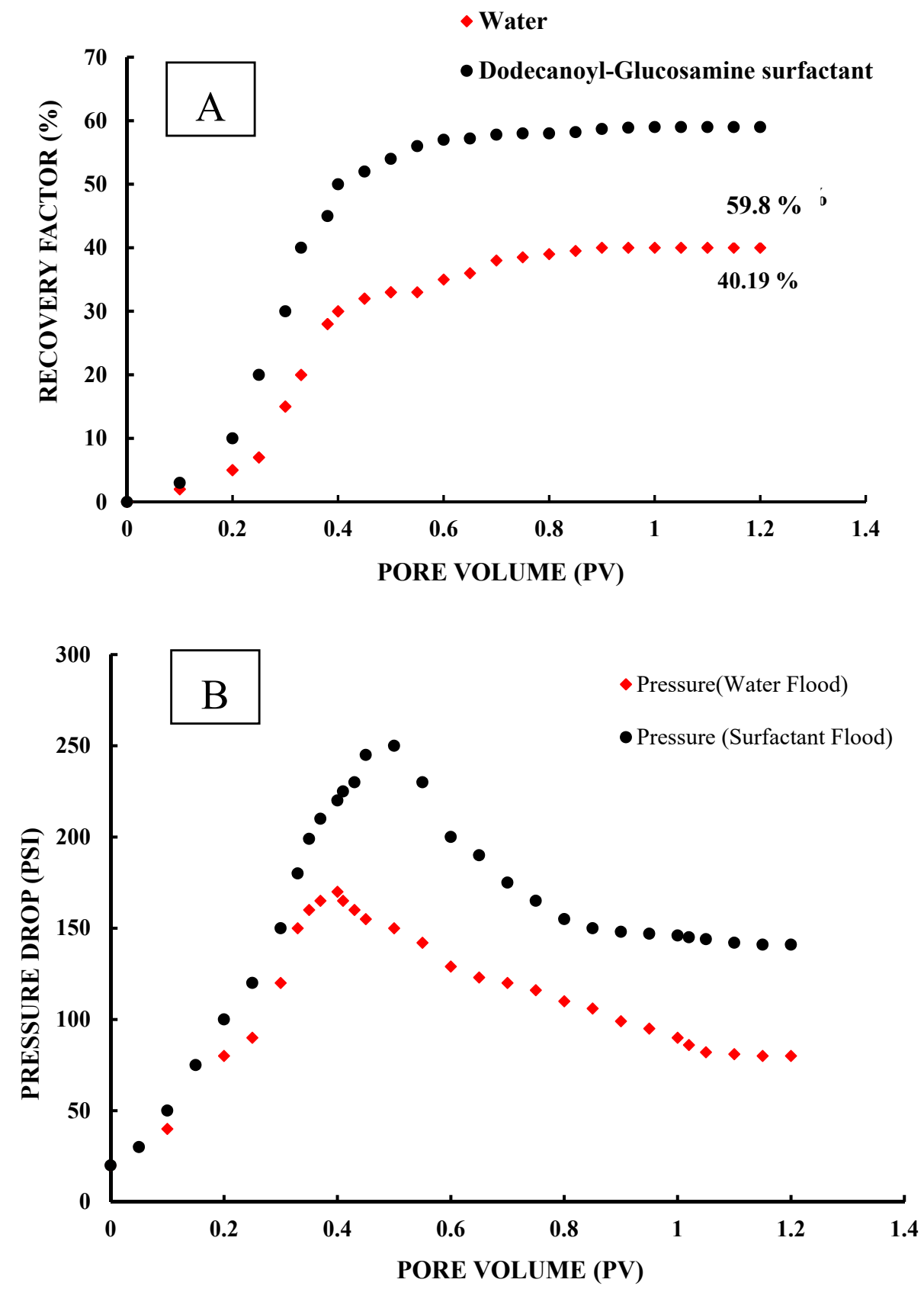

Figure 11. Core flooding results at ambient temperature and condition. (A) Oil recovery percentage versus injected pore volumes for both surfactant and water flooding. (B) Pressure drop curves for both surfactant and water flooding at different injected pore volumes.

Regarding the results of the conducted flooding experiments conducted in this section, an increase in the final oil recovery factor showed that this surfactant could enhance the oil recovery by the proof of displacement test of core flooding experiment. To obtain further validation on the effectiveness of this material in chemical enhanced oil recovery there is a need to authorize that the reason of this oil recovery increase was the wettability optimization using this surfactant. The Johnson, Bossler and Neumann (JBN) method was applied on the overall pressure drops during the experiment and the effluent phase ratio versus time during two phase displacements to obtain the relative permeability curves. Permeability curves for both flooding experiments (water flooding and surfactant flooding) are shown in the Figure 12 in an integrated manner to enable simultaneous comparison. 


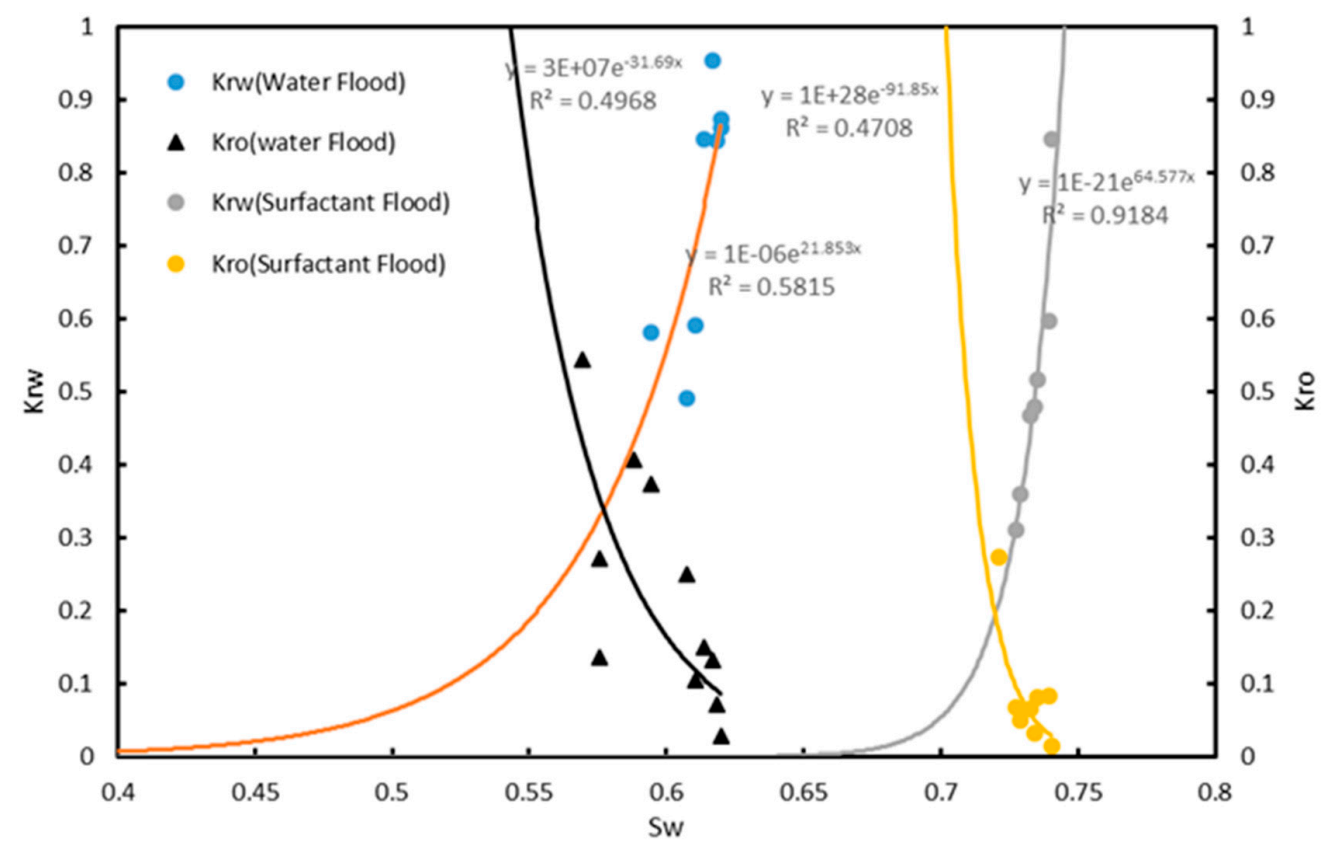

Figure 12. Relative permeability curves for water flooding and surfactant flooding (as a CEOR method) using Johnson, Bossler and Neumann (JBN) method of relative permeability prediction.

JBN-governed relative permeability curves (RPC) for water flooding are located in the left side of Figure 12 and the RPC of surfactant flooding is located in the right section of Figure 12. The large difference in the positioning of the figures of water flooding and surfactant flooding presents that a great difference in the wettability state of the system is conducted in the surfactant flooding. Intersection points of each RPC shows the wettability condition of the system [62]. The intersection point of the water flooding RPC is located in the water saturation position of 57.5 percent and the surfactant flooding showed an intersection point that is located in the higher water saturation compared to water RPC and the approximate location is 72 percent of water saturation. The shifting of the intersection point to higher water saturations shows the wettability shifting to a more water wet tendency and the resulted enhancement in oil recovery is initiated partially from this phenomenon. The residual oil saturation is decreased in surfactant flooding and the irreducible water saturation is increased compared to the water flooding experiment and its RPC and a decrease in the immobile and trapped oil resulted in surfactant flooding, which proves that the increased oil recovery is validated.

\section{Conclusions}

This article is based on the experimental investigation of the dodecanoyl-glucosamine surfactant and its associated effects on oil recovery, IFT reduction, and wettability alteration. Pendant drop method was used to measure the IFT, contact angle method was used to measure the wettability [63], and core flooding experiments were conducted to measure the oil recovery factor. Wettability alteration to more water-wet conditions and IFT reduction are the fundamental factors to enhance the oil recovery. In this study, the dodecanoyl-glucosamine surfactant was very effective to reduce the contact angle from $148.93^{\circ}$ to $65.54^{\circ}$, whereas IFT was reduced from 30 to 14 dynes $/ \mathrm{cm}$, which is $53.33 \%$ reduction at optimum conditions. The CMC of the dodecanoyl-glucosamine surfactant was measured at $843 \mathrm{ppm}$ by measuring $\mathrm{pH}$, density, conductivity, and turbidity, which then was used as the optimum concentration for core flooding experiments. The dodecanoyl-glucosamine surfactant improved the oil recovery from $40.19 \%$ to $59 \%$, an extra $18.81 \%$ of oil production. In a nutshell, to correctly gauge the feasibility of this green novel surfactant, it is pertinent to quantify comprehensive study at field scale for the benefit of the environment and oil industry. We thus conclude that injecting the dodecanoyl-glucosamine 
surfactant as a tertiary recovery method is helpful to increase the oil production, and thus may meet the world's energy demands.

Author Contributions: Data curation, M.A.T. and J.A.A.; Formal analysis, G.Z. and M.A.T.; Investigation, O.M.H.; Project administration, M.A.; Resources, A.K.M.; Software, J.A.A. and G.Z.; Supervision, A.K.M. and A.K.; Validation, A.K.M., A.K. and M.A.; Writing-original draft, O.M.H. and M.A.; Writing-review \& editing, M.A. and A.K.M. All authors have read and agreed to the published version of the manuscript.

Acknowledgments: The authors acknowledge support provided from Petroleum University of Technology, Iran and Edith Cowan University, Australia for technical and experimental support.

Conflicts of Interest: The authors declare no competing conflict of interest.

\section{References}

1. Memon, K.R.; Mahesar, A.A.; Ali, M.; Tunio, A.H.; Mohanty, U.S.; Akhondzadeh, H.; Awan, F.U.R.; Iglauer, S.; Keshavarz, A. Influence of cryogenic liquid nitrogen on petro-physical characteristics of mancos shale: An experimental investigation. Energy Fuels 2020, 34, 2160-2168. [CrossRef]

2. Mahesar, A.A.; Shar, A.M.; Ali, M.; Tunio, A.H.; Uqailli, M.A.; Mohanty, U.S.; Akhondzadeh, H.; Iglauer, S.; Keshavarz, A. Morphological and petro physical estimation of eocene tight carbonate formation cracking by cryogenic liquid nitrogen; a case study of Lower Indus basin, Pakistan. J. Pet. Sci. Eng. 2020, 192, 107318. [CrossRef]

3. Alvarado, V.; Manrique, E. Enhanced oil recovery: An update review. Energies 2010, 3, 1529-1575. [CrossRef]

4. Blunt, M.; Fayers, F.J.; Orr, F.M., Jr. Carbon dioxide in enhanced oil recovery. Energy Convers. Manag. 1993, 34, 1197-1204. [CrossRef]

5. Kamal, M.S.; Hussein, I.A.; Sultan, A.S. Review on surfactant flooding: Phase behavior, retention, IFT, and field applications. Energy Fuels 2017, 31, 7701-7720. [CrossRef]

6. Emadi, S.; Shadizadeh, S.R.; Manshad, A.K.; Rahimi, A.M.; Mohammadi, A.H. Effect of nano silica particles on Interfacial Tension (IFT) and mobility control of natural surfactant (Cedr Extraction) solution in enhanced oil recovery process by nano-surfactant flooding. J. Mol. Liq. 2017, 248, 163-167. [CrossRef]

7. Hirasaki, G.J.; Miller, C.A.; Puerto, M. Recent Advances in Surfactant EOR, Proceedings of the IPTC 2008: International Petroleum Technology Conference, Kuala Lumpur, Malaysia, 3-5 December 2008; Society of Petroleum Engineers: Denver, CO, USA, 2008.

8. Chukwudeme, E.A.; Hamouda, A.A. Enhanced oil recovery (EOR) by miscible $\mathrm{CO}_{2}$ and water flooding of asphaltenic and non-asphaltenic oils. Energies 2009, 2, 714-737. [CrossRef]

9. Sun, X.; Zhang, Y.; Chen, G.; Gai, Z. Application of nanoparticles in enhanced oil recovery: A critical review of recent progress. Energies 2017, 10, 345. [CrossRef]

10. Ali, M.; Al-Anssari, S.; Shakeel, M.; Arif, M.; Dahraj, N.U.; Iglauer, S. Influence of Miscible $\mathrm{CO}_{2}$ Flooding on Wettability and Asphaltene Precipitation in Indiana Lime Stone, Proceedings of the SPE/IATMI Asia Pacific Oil E Gas Conference and Exhibition, Jakarta, Indonesia, 17-19 October 2017; Society of Petroleum Engineers: Jakarta, Indonesia, 2017.

11. Ali, M.; Dahraj, N.U.; Haider, S.A. Study of Asphaltene Precipitation during $\mathrm{CO}_{2}$ Injection in Light Oil Reservoirs, Proceedings of the SPE/PAPG Pakistan Section Annual Technical Conference, Islamabad, Pakistan, 24-25 November 2015; Society of Petroleum Engineers: Islamabad, Pakistan, 2015.

12. Nowrouzi, I.; Manshad, A.K.; Mohammadi, A.H. Effects of ions and dissolved carbon dioxide in brine on wettability alteration, contact angle and oil production in smart water and carbonated smart water injection processes in carbonate oil reservoirs. Fuel 2019, 235, 1039-1051. [CrossRef]

13. Le Van, S.; Chon, B.H. Chemical flooding in heavy-oil reservoirs: From technical investigation to optimization using response surface methodology. Energies 2016, 9, 711. [CrossRef]

14. Hamouda, A.A.; Bagalkot, N. Effect of salts on interfacial tension and $\mathrm{CO}_{2}$ mass transfer in carbonated water injection. Energies 2019, 12, 748. [CrossRef]

15. Najimi, S.; Nowrouzi, I.; Manshad, A.K.; Farsangi, M.H.; Hezave, A.Z.; Ali, J.A.; Keshavarz, A.; Mohammadi, A.H. Investigating the effect of [C $8 \mathrm{Py}][\mathrm{Cl}]$ and $[\mathrm{C} 18 \mathrm{Py}][\mathrm{Cl}]$ ionic liquids on the water/oil interfacial tension by considering Taguchi method. J. Pet. Explor. Prod. Technol. 2019, 9, 2933-2941. [CrossRef]

16. Jha, N.; Ali, M.; Sarmadivaleh, M.; Iglauer, S.; Barifcani, A.; Lebedev, M.; Sangwai, J. Low Salinity Surfactant Nanofluids for Enhanced $\mathrm{CO}_{2}$ Storage Application at High Pressure and Temperature, Proceedings of the Fifth 
$\mathrm{CO}_{2}$ Geological Storage Workshop, Utrecht, The Netherlands, 21-23 November 2018; European Association of Geoscientists \& Engineers: Utrecht, The Netherlands, 2018; pp. 1-4.

17. Ali, J.A.; Kolo, K.; Manshad, A.K.; Stephen, K.D. Potential application of low-salinity polymeric-nanofluid in carbonate oil reservoirs: IFT reduction, wettability alteration, rheology and emulsification characteristics. J. Mol. Liq. 2019, 284, 735-747. [CrossRef]

18. Green, D.W.; Willhite, G.P. Enhanced Oil Recovery; Henry L. Doherty Memorial Fund of AIME, Society of Petroleum Engineers: Richardson, TX, USA, 1998; Volume 6.

19. Bahraminejad, H.; Khaksar Manshad, A.; Riazi, M.; Ali, J.A.; Sajadi, S.M.; Keshavarz, A. CuO/TiO $2 / \mathrm{PAM}$ as a novel introduced hybrid agent for water-oil interfacial tension and wettability optimization in chemical enhanced oil recovery. Energy Fuels 2019, 33, 10547-10560. [CrossRef]

20. Howe, A.M.; Clarke, A.; Mitchell, J.; Staniland, J.; Hawkes, L.; Whalan, C. Visualising surfactant enhanced oil recovery. Colloids Surf. A Physicochem. Eng. Asp. 2015, 480, 449-461. [CrossRef]

21. Jha, N.K.; Ali, M.; Iglauer, S.; Lebedev, M.; Roshan, H.; Barifcani, A.; Sangwai, J.S.; Sarmadivaleh, M. Wettability alteration of quartz surface by low-salinity surfactant nanofluids at high-pressure and high-temperature conditions. Energy Fuels 2019, 33, 7062-7068. [CrossRef]

22. Jha, N.K.; Lebedev, M.; Iglauer, S.; Ali, M.; Roshan, H.; Barifcani, A.; Sangwai, J.S.; Sarmadivaleh, M. Pore scale investigation of low salinity surfactant nanofluid injection into oil saturated sandstone via X-ray micro-tomography. J. Colloid Interface Sci. 2020, 562, 370-380. [CrossRef]

23. Ali, M.; Al-Anssari, S.; Arif, M.; Barifcani, A.; Sarmadivaleh, M.; Stalker, L.; Lebedev, M.; Iglauer, S. Organic acid concentration thresholds for ageing of carbonate minerals: Implications for $\mathrm{CO}_{2}$ trapping/storage. J. Colloid Interface Sci. 2019, 534, 88-94. [CrossRef]

24. Arif, M.; Abu-Khamsin, S.A.; Zhang, Y.; Iglauer, S. Experimental investigation of carbonate wettability as a function of mineralogical and thermo-physical conditions. Fuel 2020, 264, 116846. [CrossRef]

25. Al-Anssari, S.; Arain, Z.-U.-A.; Barifcani, A.; Keshavarz, A.; Ali, M.; Iglauer, S. Influence of Pressure and Temperature on $\mathrm{CO}_{2}$-Nanofluid Interfacial Tension: Implication for Enhanced Oil Recovery and Carbon Geosequestration, Proceedings of the Abu Dhabi International Petroleum Exhibition E Conference, Abu Dhabi, United Arab Emirates, 12-15 November 2018; Society of Petroleum Engineers: At Abu Dhabi, UAE, 2018.

26. Ali, M. Effect of Organic Surface Concentration on $\mathrm{CO}_{2}$-Wettability of Reservoir Rock. Master's Thesis, Curtin University, Bentley, WA, Australia, 2018.

27. Cayias, J.; Schechter, R.S.; Wade, W. The utilization of petroleum sulfonates for producing low interfacial tensions between hydrocarbons and water. J. Colloid Interface Sci. 1977, 59, 31-38. [CrossRef]

28. Al-Sabagh, A. Surface activity and thermodynamic properties of water-soluble polyester surfactants based on 1, 3-dicarboxymethoxybenzene used for enhanced oil recovery. Polym. Adv. Technol. 2000, 11, 48-56. [CrossRef]

29. Shuler, P.J.; Tang, H.; Lu, Z.; Tang, Y. Chemical Process for Improved Oil Recovery from Bakken Shale, Proceedings of the Canadian Unconventional Resources Conference, Calgary, AB, Canada, 15-17 November 2011; Society of Petroleum Engineers: Calgary, AB, Canada, 2011.

30. Cheng, A.; Kwan, J.T. Optimal Injection Design Utilizing Tracer and Simulation in a Surfactant Pilot for a Fractured Carbonate Yates Field, Proceedings of the SPE Improved Oil Recovery Symposium, Tulsa, OK, USA, 14-18 April 2012; Society of Petroleum Engineers: Tulsa, OK, USA, 2012.

31. Asl, H.F.; Zargar, G.; Manshad, A.K.; Takassi, M.A.; Ali, J.A.; Keshavarz, A. Experimental investigation into l-Arg and 1-Cys eco-friendly surfactants in enhanced oil recovery by considering IFT reduction and wettability alteration. Pet. Sci. 2020, 17, 105-117. [CrossRef]

32. Deng, X.; Kamal, M.S.; Patil, S.; Hussain, S.M.S.; Zhou, X. A review on wettability alteration in carbonate rocks: Wettability modifiers. Energy Fuels 2019, 34, 31-54. [CrossRef]

33. Ahmadi, M.A.; Galedarzadeh, M.; Shadizadeh, S.R. Wettability alteration in carbonate rocks by implementing new derived natural surfactant: Enhanced oil recovery applications. Transp. Porous Media 2015, 106, 645-667. [CrossRef]

34. Karimi, M.; Al-Maamari, R.S.; Ayatollahi, S.; Mehranbod, N. Wettability alteration and oil recovery by spontaneous imbibition of low salinity brine into carbonates: Impact of $\mathrm{Mg} 2+, \mathrm{SO} 42-$ and cationic surfactant. J. Pet. Sci. Eng. 2016, 147, 560-569. [CrossRef]

35. Ghosh, B.; Li, X. Effect of surfactant composition on reservoir wettability and scale inhibitor squeeze lifetime in oil wet carbonate reservoir. J. Pet. Sci. Eng. 2013, 108, 250-258. [CrossRef] 
36. Alveskog, P.; Holt, T.; Torsaeter, O. The effect of surfactant concentration on the Amott wettability index and residual oil saturation. J. Pet. Sci. Eng. 1998, 20, 247-252. [CrossRef]

37. Akhondzadeh, H.; Keshavarz, A.; Al-Yaseri, A.Z.; Ali, M.; Awan, F.U.R.; Wang, X.; Yang, Y.; Iglauer, S.; Lebedev, M. Pore-scale analysis of coal cleat network evolution through liquid nitrogen treatment: A micro-computed tomography investigation. Int. J. Coal Geol. 2020, 219, 103370. [CrossRef]

38. Rebello, S.; Asok, A.K.; Mundayoor, S.; Jisha, M. Surfactants: Toxicity, remediation and green surfactants. Environ. Chem. Lett. 2014, 12, 275-287. [CrossRef]

39. Olajire, A.A. Review of ASP EOR (alkaline surfactant polymer enhanced oil recovery) technology in the petroleum industry: Prospects and challenges. Energy 2014, 77, 963-982. [CrossRef]

40. Vryzas, Z.; Kelessidis, V.C. Nano-based drilling fluids: A review. Energies 2017, 10, 540. [CrossRef]

41. Epelle, E.I.; Gerogiorgis, D.I. A multiparametric CFD analysis of multiphase annular flows for oil and gas drilling applications. Comput. Chem. Eng. 2017, 106, 645-661. [CrossRef]

42. Giger, W.; Brunner, P.H.; Schaffner, C. 4-Nonylphenol in sewage sludge: Accumulation of toxic metabolites from nonionic surfactants. Science 1984, 225, 623-625. [CrossRef] [PubMed]

43. Kvestak, R.; Ahel, M. Occurrence of toxic metabolites from nonionic surfactants in the Krka river estuary. Ecotoxicol. Environ. Saf. 1994, 28, 25-34. [CrossRef] [PubMed]

44. Lechuga, M.; Fernández-Serrano, M.; Jurado, E.; Núñez-Olea, J.; Ríos, F. Acute toxicity of anionic and non-ionic surfactants to aquatic organisms. Ecotoxicol. Environ. Saf. 2016, 125, 1-8. [CrossRef]

45. Ali, M.; Jarni, H.H.; Aftab, A.; Ismail, A.R.; Saady, N.M.C.; Sahito, M.F.; Keshavarz, A.; Iglauer, S.; Sarmadivaleh, M. Nanomaterial-based drilling fluids for exploitation of unconventional reservoirs: A review. Energies 2020, 13, 3417. [CrossRef]

46. Aftab, A.; Ali, M.; Sahito, M.F.; Mohanty, U.S.; Jha, N.K.; Akhondzadeh, H.; Azhar, M.R.; Ismail, A.R.; Keshavarz, A.; Iglauer, S. Environmental friendliness and high performance of multifunctional tween 80/ZnO-Nanoparticles-Added water-based drilling fluid: An experimental approach. Sustain. Chem. Eng. 2020. [CrossRef]

47. Manshad, A.K.; Rezaei, M.; Moradi, S.; Nowrouzi, I.; Mohammadi, A.H. Wettability alteration and interfacial tension (IFT) reduction in enhanced oil recovery (EOR) process by ionic liquid flooding. J. Mol. Liq. 2017, 248, 153-162. [CrossRef]

48. Hou, B.-F.; Wang, Y.-F.; Huang, Y. Mechanistic study of wettability alteration of oil-wet sandstone surface using different surfactants. Appl. Surf. Sci. 2015, 330, 56-64. [CrossRef]

49. Nabipour, M.; Ayatollahi, S.; Keshavarz, P. Application of different novel and newly designed commercial ionic liquids and surfactants for more oil recovery from an Iranian oil field. J. Mol. Liq. 2017, 230, 579-588. [CrossRef]

50. Tavakoli, P.; Shadizadeh, S.R.; Hayati, F.; Fattahi, M. Effect of synthesized nanoparticles and Henna-Tragacanth solutions on oil/water interfacial tension: Nanofluids stability considerations. Petroleum 2020. [CrossRef]

51. Ravi, S.; Shadizadeh, S.; Moghaddasi, J. Core flooding tests to investigate the effects of IFT reduction and wettability alteration on oil recovery: Using mulberry leaf extract. Pet. Sci. Technol. 2015, 33, 257-264. [CrossRef]

52. Iglauer, S. $\mathrm{CO}_{2}$-water-rock wettability: Variability, influencing factors, and implications for $\mathrm{CO}_{2}$ geostorage. Acc. Chem. Res. 2017, 50, 1134-1142. [CrossRef] [PubMed]

53. Al-Anssari, S.; Nwidee, L.; Ali, M.; Sangwai, J.S.; Wang, S.; Barifcani, A.; Iglauer, S. Retention of Silica Nanoparticles in Limestone Porous Media, Proceedings of the SPE/IATMI Asia Pacific Oil E Gas Conference and Exhibition, Jakarta, Indonesia, 17-19 October 2017; Society of Petroleum Engineers: Jakarta, Indonesia, 2017.

54. Ali, M.; Arif, M.; Sahito, M.F.; Al-Anssari, S.; Keshavarz, A.; Barifcani, A.; Stalker, L.; Sarmadivaleh, M.; Iglauer, $\mathrm{S}$. $\mathrm{CO}_{2}$-wettability of sandstones exposed to traces of organic acids: Implications for $\mathrm{CO}_{2}$ geo-storage. Int. J. Greenh. Gas. Control. 2019, 83, 61-68. [CrossRef]

55. Takassi, M.A.; Zargar, G.; Madani, M.; Zadehnazari, A. The preparation of an amino acid-based surfactant and its potential application as an EOR agent. Pet. Sci. Technol. 2017, 35, 385-391. [CrossRef]

56. Ramshini, A. Synthesis and Study of a Novel Lauroyl Cysteine Surfactant as Water-Oil Demulsifier and Modeling with Fuzzy Logic Design. (Unpublished doctoral dissertation). Ph.D. Thesis, PUT, Abadan, Iran, 2017. 
57. Madani, M.; Zargar, G.; Takassi, M.A.; Daryasafar, A.; Wood, D.A.; Zhang, Z. Fundamental investigation of an environmentally-friendly surfactant agent for chemical enhanced oil recovery. Fuel 2019, 238, $186-197$. [CrossRef]

58. Pal, N.; Saxena, N.; Laxmi, K.D.; Mandal, A. Interfacial behaviour, wettability alteration and emulsification characteristics of a novel surfactant: Implications for enhanced oil recovery. Chem. Eng. Sci. 2018, 187, 200-212. [CrossRef]

59. Al-Anssari, S.; Ali, M.; Memon, S.; Bhatti, M.A.; Lagat, C.; Sarmadivaleh, M. Reversible and irreversible adsorption of bare and hybrid silica nanoparticles onto carbonate surface at reservoir condition. Petroleum 2019. [CrossRef]

60. Arif, M.; Abu-Khamsin, S.; Iglauer, S. Wettability of rock/ $\mathrm{CO}_{2} /$ brine and rock/oil/ $/ \mathrm{CO}_{2}$-enriched-brine systems: Critical parametric analysis and future outlook. Adv. Colloid Interface Sci. 2019. [CrossRef]

61. Ali, M.; Sahito, M.F.; Jha, N.K.; Memon, S.; Keshavarz, A.; Iglauer, S.; Saeedi, A.; Sarmadivaleh, M. Effect of Nanofluid on $\mathrm{CO}_{2}$-wettability reversal of sandstone formation; implications for $\mathrm{CO}_{2}$ geo-storage. J. Colloid Interface Sci. 2019. [CrossRef]

62. Alizadeh, A.H.; Keshavarz, A.; Haghighi, M. Flow Rate Effect on Two-Phase Relative Permeability in Iranian Carbonate Rocks, Proceedings of the SPE Middle East oil and gas show and conference, Manama, Bahrain, 11-14 March 2007; Society of Petroleum Engineers: Manama, Bahrain, 2007.

63. Ali, M.; Aftab, A.; Arain, Z.-U.-A.; Al-Yaseri, A.; Roshan, H.; Saeedi, A.; Iglauer, S.; Sarmadivaleh, M. Influence of Organic Acids Concentration on Wettability Alteration of Cap-rock: Implications for $\mathrm{CO}_{2}$ Trapping/Storage. Appl. Mater. Interfaces. 2020. [CrossRef]

(C) 2020 by the authors. Licensee MDPI, Basel, Switzerland. This article is an open access article distributed under the terms and conditions of the Creative Commons Attribution (CC BY) license (http://creativecommons.org/licenses/by/4.0/). 